\title{
Geodiversity Examples of Morocco: From Inventory to Regional Geotourism Development
}

\author{
Hassan El Hadi1 ${ }^{*}$, Abdelfatah Tahiri², José Brilha3 ${ }^{3}$, Ayoub El Maidani4, Bouamar Baghdad5, \\ Abdelkrim Zaidi6 \\ ${ }^{1}$ Laboratory of Applied Geology, Geomatic and Environment/Sciences Faculty of Ben M'Sik, University Hassan II \\ of Casablanca, Casablanca, Morocco \\ ${ }^{2}$ Geology and Remote Sensing Laboratory, URAC46, Scientific Institute, University of Rabat, Morocco \\ ${ }^{3}$ Institute of Earth Sciences, Pole of the University of Minho, Campus de Gualtar, Braga, Portugal \\ ${ }^{4}$ University Hassan II of Casablanca, Casablanca, Morocco \\ ${ }^{5}$ Hassan II Agronomy and Veterinary Institute, Rabat, Morocco \\ ${ }^{6}$ Université Ibn Zohr, Agadir, Morocco \\ Email: ${ }^{*}$ elhadihas@gmail.com
}

Received 13 April 2015; accepted 7 September 2015; published 10 September 2015

Copyright ( 2015 by authors and Scientific Research Publishing Inc.

This work is licensed under the Creative Commons Attribution International License (CC BY).

http://creativecommons.org/licenses/by/4.0/

c) (i) Open Access

\begin{abstract}
The soil and subsoil of Morocco are rich in geological phenomena that bear the imprint of a history which goes back in time more than 2000 million years. Very many geologically remarkable sites exposed in accessible outcrops, with good quality remained unknown to the general public and therefore deserved to be vulgarized. It is a memory to acquaint the present generations but also to preserve for future generations. In total, a rich geological heritage in many ways: Varied landscapes, international stratotypes, various geological structures, varied rocks, mineral associations, a huge procession offossiles, remnants of oceanic crust (ophiolites) among oldests ones in the world (800 $\mathrm{my}$ ), etc. For this geological heritage, an approach of an overall inventory is needed, both regionally and nationally, taking into account all the skills of the earth sciences. This will put the item on the natural (geological) potentialities as a lever for sustainable regional development. For this, it is necessary to implement a strategy of "geoconservation" for the preservation and assessment of the geological heritage. A website "lithothèque du Maroc" is under construction.
\end{abstract}

\section{Keywords}

Geodiversity, Morocco, Inventory, Regional Development

\footnotetext{
${ }^{*}$ Corresponding author.
}

How to cite this paper: El Hadi, H., Tahiri, A., Brilha, J., El Maidani, A., Baghdad, B. and Zaidi, A. (2015) Geodiversity Examples of Morocco: From Inventory to Regional Geotourism Development. Open Journal of Ecology, 5, 409-419. 


\section{Introduction}

Morocco's geology is better documented regarding the didactic aspects [1] and references inside. It is very rich in sedimentological, magmatic, tectono-metamorphic, paleontological and geomorphologic phenomena, which bear the imprint of a history going back in time over 2000 million years. However, remarkable geological sites, which are numerous, still poorly understood by the general public and therefore deserve more attention. They are usually exposed in easily accessible and well preserved outcrops. Few people have a real understanding of the nature, age, conditions and phenomena of implementation of rocks exposed on Moroccan soil. This is a memory to share with current generations but also to preserve for future generations.

Moroccan geological diversity is an asset for sustainable regional development in terms of geological tourism and geo-eco-tourism.

The purpose of this paper is to present some remarkable and singular geological sites that can sustain the Moroccan economy of geotourism sector.

\section{The Geological Heritage: From Inventory to Geoconservation}

\subsection{The Geological Heritage}

Geological heritage tells the story of the earth since its origins and encompasses all objects and sites that symbolize the memory of the earth. It is also a legacy we leave to future generations so that they can enjoy the geological component.

The expression "Geological heritage" considers all objects and sites related to the disciplines of Earth Sciences such as rocks, minerals, fossils, outcrops and landscapes, or any natural object that has heritage value [2]-[5]. An outstanding geological site can be either (in situ and/or ex situ): (1) a geosite (locality or site) that has a remarkable geological importance; (2) a Geopark: region or area comprising various elements of particular geological importance, rarity or aesthetic appeal, and offers various courses of discovery of these elements; or (3) a collection of fossils, minerals or rocks, etc.

\subsection{Inventory of Geological Heritage}

The inventory is a knowledge reference that has first of all an informative vocation. It aims at:

- Identification, in situ and ex situ, of all the sites and objects that have a geological interest;

- Data entry and information processing (location, geological features, geo-touristic importance, etc.);

- Validation of the significant scientific, academic, scholar and cultural heritage sites by national and international experts;

- Assessment of their vulnerability and potential needs and means to implement in order to protect them (concerning protection).

The inventory of geological sites takes into account several criteria including the geological interest, educational value, tourism and economic interests as well as aesthetic and rarity of the site.

These criteria must be evaluated to attribute for each site a heritage value. The higher score is attributed to the geologically remarkable site (as stratotype site).

\subsection{Why and How Save the Geological Heritage?}

Once sampled (or destroyed), geological objects are not recovering. This is the main reason given for protection of geological objects. Aesthetic objects are often threatened by artisanal and/or industrial exploitation (sometimes unintentional). The protection of a lands form, a rock, a mineral, a fossil of a remarkable geological structure or a deposit is not solely scientific reasons but also tourism and cultural:

- To ensure the protection and safeguarding of the geological diversity against natural disasters and/or human intervention;

- To promote a better understanding of the geology;

- To preserve the aesthetic value;

- To make this heritage known and accessible to all;

- To promote and develop the participation of this heritage to economic development: e.g. geological hiking. In order to protect geological heritage, several actions must be taken, including: 
- Establishment of a legal framework;

- Cooperation with geoscience organizations for the protection and enhancement of the geological heritage;

- Consultation with elected officials, policy makers, local authorities and also the public, scientists, teachers, associations, tourism, neighborhood;

- Implementation of regional museological parks, scientific road signs, etc.;

- The GIS development.

\subsection{The Geological Heritage: From Geoconservation to Regional Geotourism Development}

Morocco has a very rich and varied geological heritage. Diversity of landscapes and mineralization, a wide range of igneous, metamorphic and sedimentary rocks, tectonic structures (faults, folds and unconformities) and many fossil species (abundance and excellent state of preservation), prehistoric caves or appointed, etc., are memories of all geological time for more than 2000 million years to the present. In addition to several museums and regional heritage recovery centers, this geodiversity, evenly distributed throughout the country, is an asset for economic prosperity, regional sustainable development and tourism (job creation). It has also an educational, cultural and pedagogical utility (guides land outputs).

In Morocco, the inventory of geological heritage sites is still in its premature. Recognizing the importance of the inventory of geological sites and identification of geological features in regional development, the defenders of this heritage are sounding the alarm. Scientists (through symposium, topical seminars and scientific publications) should play an important role in elucidating the significance of the inventory and its impact on the sustainable development of the various regions of the country. In that sense, the Hassan II Academy of Sciences and Technology has financed projects on Moroccan geoheritage. This issue is also often discussed in scientific events organized by the Moroccan Earth Sciences Association (AMST). Scientific publications in specialized journals begin to emerge [6]-[8].

In terms of geoconservation, broad concept which means inventory, valorization and protection of geological heritage, Morocco is required to take the initiative and follow strategies developed by many European neighboring countries, including Spain, Portugal, France, and United Kingdom... [9]-[11].

Several factors are essential to ensure the success of geoconservation strategy, including:

- National and international competencies;

- Partnerships with tourism professionals, namely tourism offices, lodging and tourist guides;

- Policy makers, elected officials, local community...

\subsection{What Extension Strategy for Moroccan Geoheritage?}

The inventory of the Moroccan geoheritage is still at the beginning stage. Various initiatives have been taken by academics through scientific events and civil society concerned not only with heritage deterioration but also its use as a vector of sustainable geotourism development. The popularization of geoheritage may take place from several ways:

- Elaboration of geo-tourism guides, prospectuses, explanatory panels, websites etc. (Figure 1);

- Media coverage: symposiums, round tables, museums, meetings with elected officials, local population...;

- Actions to undertake: elected officials, political, public, researchers, local authorities, the local population;

- To promote the region as a geotouristic destination.

\section{Examples of Moroccan Geosites}

Previous geological studies, conducted throughout the country, illustrate many geological phenomena in Figure 2:

- Varied landscapes (river gorges, volcanic organs, etc.);

- International stratotype (Mid Devonian, Miocene), fossils: Stromatolites, Mud Mounds, Dinosaures, etc.;

- Outcrops of sedimentary rocks from the Precambrian (2.5 billion years) up to the present;

- Outcrops of igneous rocks related to the history of Pan-African, Rheic and Atlantic Ocean. Example of Bou Azzer Oceanic crust which is among the oldest found in the world (779 Ma ophiolites; Precambrian moho discontinuity...);

- Outcrops of metamorphic rocks witnesses of mantle up welling (kenzizites of Beni Bouzra); 

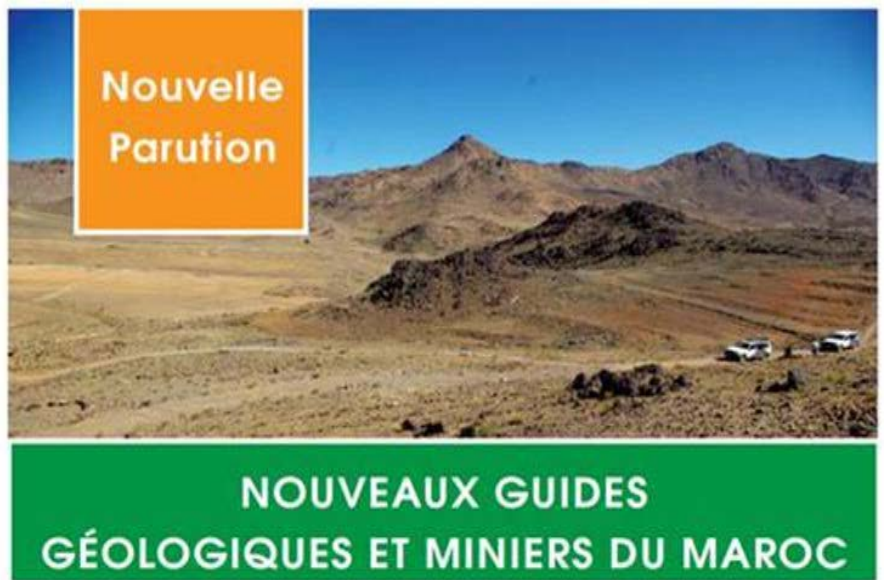

New Geological and Mining Guidebooks of Morocco

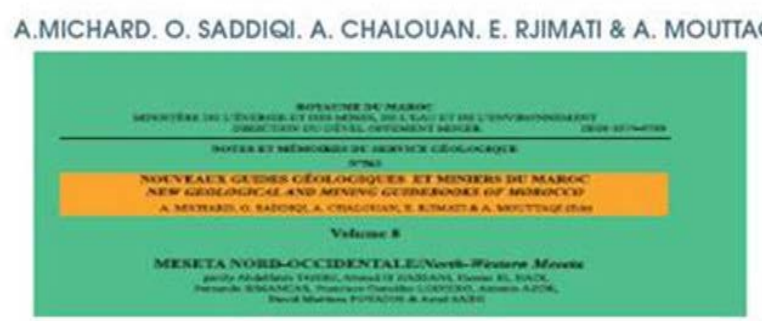

Notes \& Mém. Serv. Géol. Maroc, n 556-564, 2011

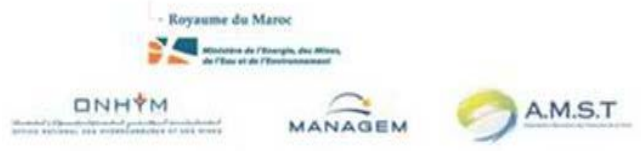

Figure 1. New geological and mining guides published in Morocco [12].

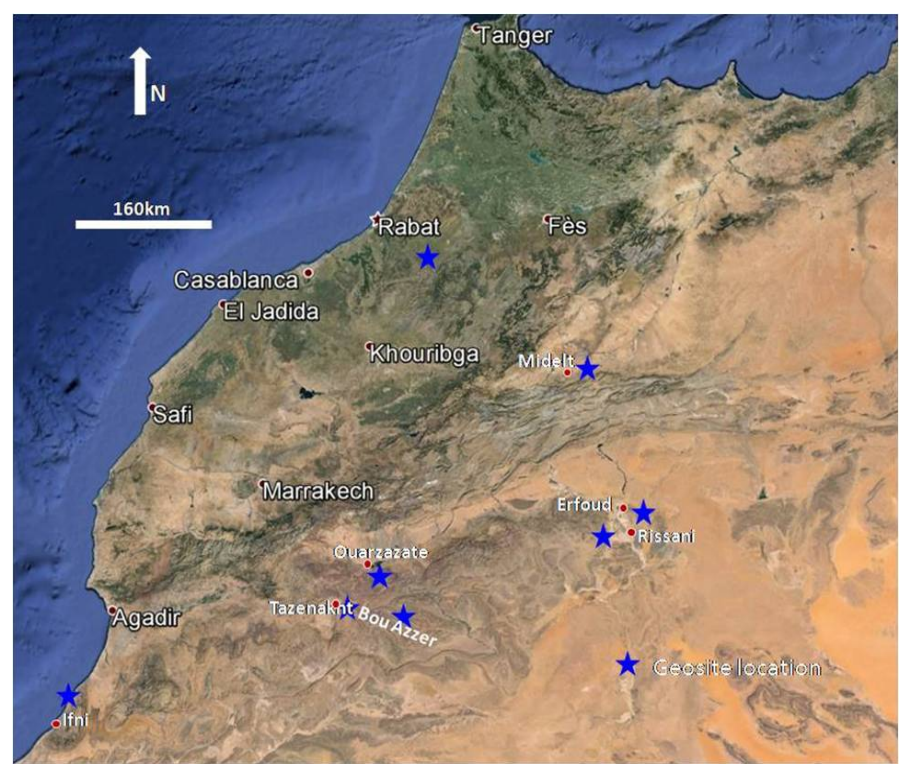

Figure 2. Geosites examples location in the Moroccan north provinces (google earth). 
- Structures related to Pan-African, Caledonian and Variscan orogeny or to recent Alpine tectonics: strike-slip and normal faults, overlaps, folds, discordance, thrust sheets;

- Thermal Sources;

- Salt mine cashed in Triassic (Khemisset) or Liassic (Mohammedia, Ain Tekki Mine) shales;

- Devonian limestone quarries (Rabat, Tiflet, Benslimane, Erfoud, Tazzarine, etc.).

\subsection{The Paleoproterozoic Granite-Late Neoproterozoic Andesites Unconformity of Tazenakht: A Gap of 1500 Ma}

This unconformity is visible $6 \mathrm{~km}$ eastern the city of Tazenakht on the road leading to Ouarzazate and Bou Azzer mine.

The Paleoproterozoic (Referred as PI on geological maps) is represented by eburnean porphyritic monzosyenogranite of Tazenakht (orthogneiss) dated to $2 \mathrm{O} 30 \mathrm{Ma}$ (SHRIMP U-Pb on zircons [13]) and forms part of what is known as the West African Craton. The top series includes highly potassic calc-alkaline volcano-clastic deposits (Conglomerate, ignimbritic rhyolite, trachytes, andesites, basaltic trachyandesites, tuffites and levels of Stromatolites) of Ediacaran age (Referred as PIII or Ouarzazate series on geological maps) (Figure 3).

\subsection{Ouarzazate Stromatolites (Figure 4)}

They are located in the Anti-Atlas, $20 \mathrm{Km}$ southern the city of Ouarzazate, on the road leading to Agdez. Stromatolites (or Conophyton Collenia sl), which correspond to silicified algal constructions, are primitive freshwater organisms indicators of early life index. They are located in a lacustrine and silicified limestone layer interbedded in the middle of the Ediacaran volcanic and volcano-clastic series of which has been dated to $571 \pm 8$ Ma (SHRIMP U-Pb on zircons) [13] (Series of Ouarzazate, as Referred PIII).

\subsection{Ophiolitic Cumulates Gabbros (Bou Azzer, Central Anti Atlas; Figure 5)}

In the Bou-Azzer El Graara inlier (South of Ouarzazate), the gabbroic cumulates, associated with Bou Azzer ophiolite, one of the oldest ophiolite of the earth, are presented as magmatic rhythmic layers distinguished by color, size and proportion of plagioclase and clinopyroxene. These gabbros, that permit the understanding of the magmatic differentiation process in the magmatic chamber, allowed dating the ophiolite to $697 \pm 8$ Ma (SHRIMP U-Pb on zircon, [16]).

\subsection{Eifelian-Givetian Stratotype of Jbel Mech Ardane (Rissani) (Figure 6)}

The Jbel Mech Irdane is a synclinal structure in the SE-Moroccan Tafilalt, $12 \mathrm{~km} \mathrm{SW}$ of Rissani city. The Jebel Mech Irdane embodies the Global Stratotype Section and Point (GSSP) for the Eifelian-Givetian Stage boundary.

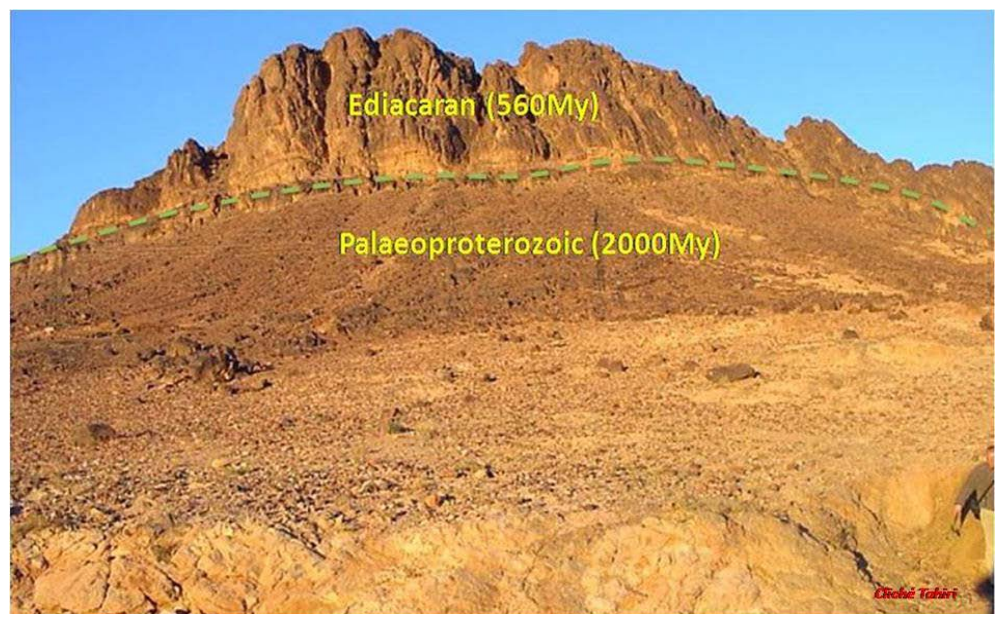

Figure 3. Unconformable Ediacaran volcanites ("PIII”) and late Ediacaran conglomerates on top of the Palaeproterozoic granite (PI). 


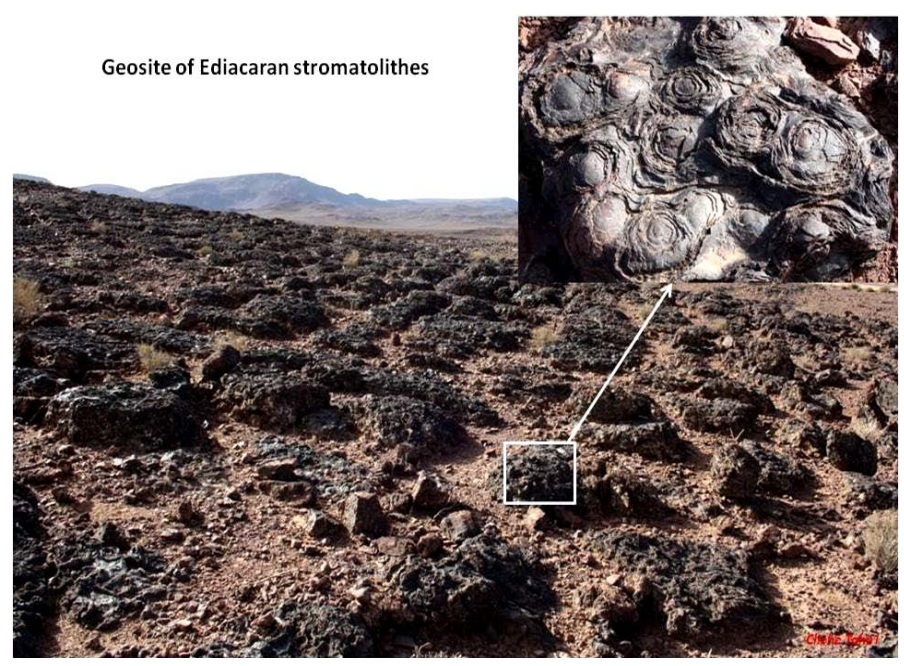

Figure 4. Ouarzazzate Ediacaran Stromatolites SE of Ouarzazate.

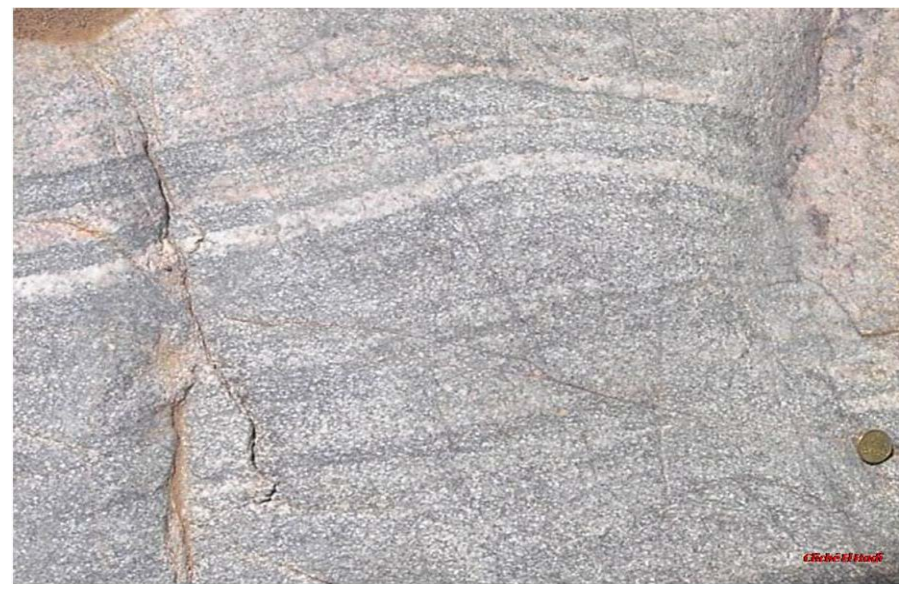

Figure 5. Ophiolitic cumulates gabbros of Bou Azzer.

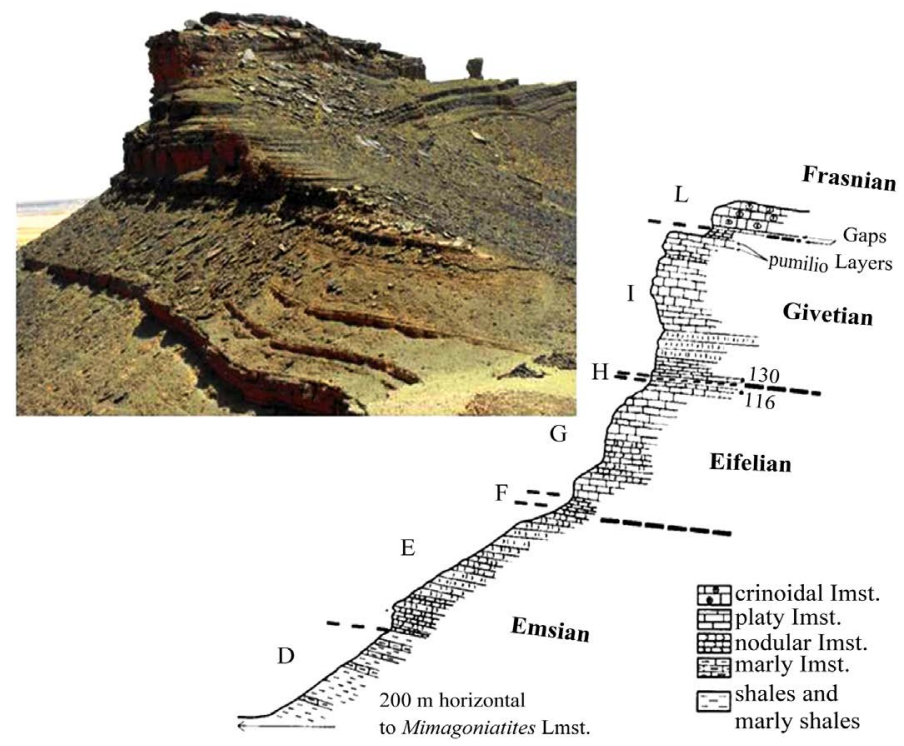

Figure 6. Eifelian-Givetianstratotype of Jbel Mech Ardane [14]. 
The International Global Stratotype Section and Point for the Eifelian-Givetian Stage boundary was recommended by SDS (Sub-commission Devonian Stratigraphy) during its field-meeting 1991 [14] and satisfied and ratified by IUGS in 1994 [15].

\subsection{Lower Devonian Mud Mounds of Jebel Hamar Laghdad (East of Erfoud, Tafilalet)}

The Lower Devonian (Emsian) limestone mounds (Kess-Kess) complex of Jebel Hamar Laghdad is considered as the best reef Devonian constructions in Africa (Figure 7). The origin and development of these mud mounds are controlled by extrinsic and intrinsic factors [16]-[18]. Extrinsic factors include the existence of a paleohigh (Lochkovian volcaniclastics), unidirectional currents and repeated storm events as well as sea level fluctuations. Intrinsic, biologically induced factors are the preferred growth of organisms on the top and the flanks of the mounds because of more favourable ecological conditions, and a rapid synsedimentary lithification of the steep mound flanks. The formation of the mounds started within the uppermost part of the bedded crinoid facies of the Kess-Kess Formation with the hydrological accumulation of a bioclastic pile. This elevation became settled by crinoids and high-diverse tabulate carats producing bioclastic sediment.

\subsection{The Triassic Serie of the North-Western Meseta (Figure 8)}

This typical Triassic series which lies uncomfortably on the lower Visean conglomerates is made up of gypsiferous clay deposits including lower argillite (sandstone at the bottom) separated by one greenish color-basaltic lavas flow (or more?) from upper argillite [19]-[21]. The assignment of Upper Triassic age (Carnian) to sedimentary rocks is achieved by palynological determinations [22]. In this basin, the thickness of the basalt flow (s) (interposed between the lower and upper shales) is variable (20 to 100 meters) [19] [20]. Local presence (north and west of Rommani) of pillow lavas structures [19] [20] suggests a marine environment setting probably subaerial. The flows are altered and contain large pods of secondary calcite. These lavas are considered as a part of the wide Central Atlantic Magmatic Province (CAMP) [23] [24].

\subsection{Prismatic Nephelinites of Oued Boulahmayel in Central Morocco (Figure 9)}

Quaternary volcanic series of central Morocco is composed of alkaline lavas highly under-saturated with silica (36\% - 55\%) and contain up to 35\% of nepheline. These lavas dated to 2.8 and 0.65 Ma consist mainly of basalts, basanites and olivine bearing-nephelinite evolving towards nephelinites and phonolites [25] [26].

These lavas form sometimes spectacular landscapes, as that of Oued Boulahmayel where we can appreciate the superposition of two lava flows, one from above which is massive formed of tephrite and that from below in pretty prisms composed of melanocratic nephelinite

\subsection{Legzira's Arches (Figure 10)}

Legzira arches are one of the best landscapes of the Moroccan Atlantic coast. The geological history of this

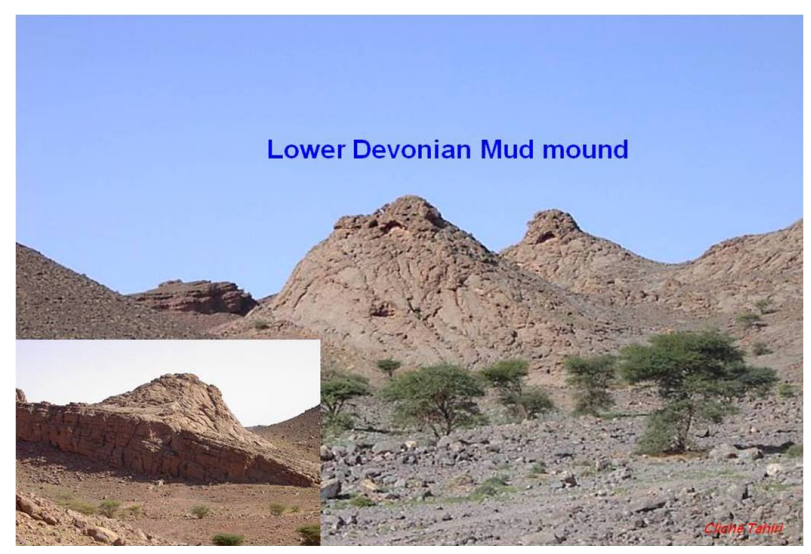

Figure 7. Lower Devonian mud mounds of Jebel Hamar Laghdad (East of Erfoud, Tafilalet). 


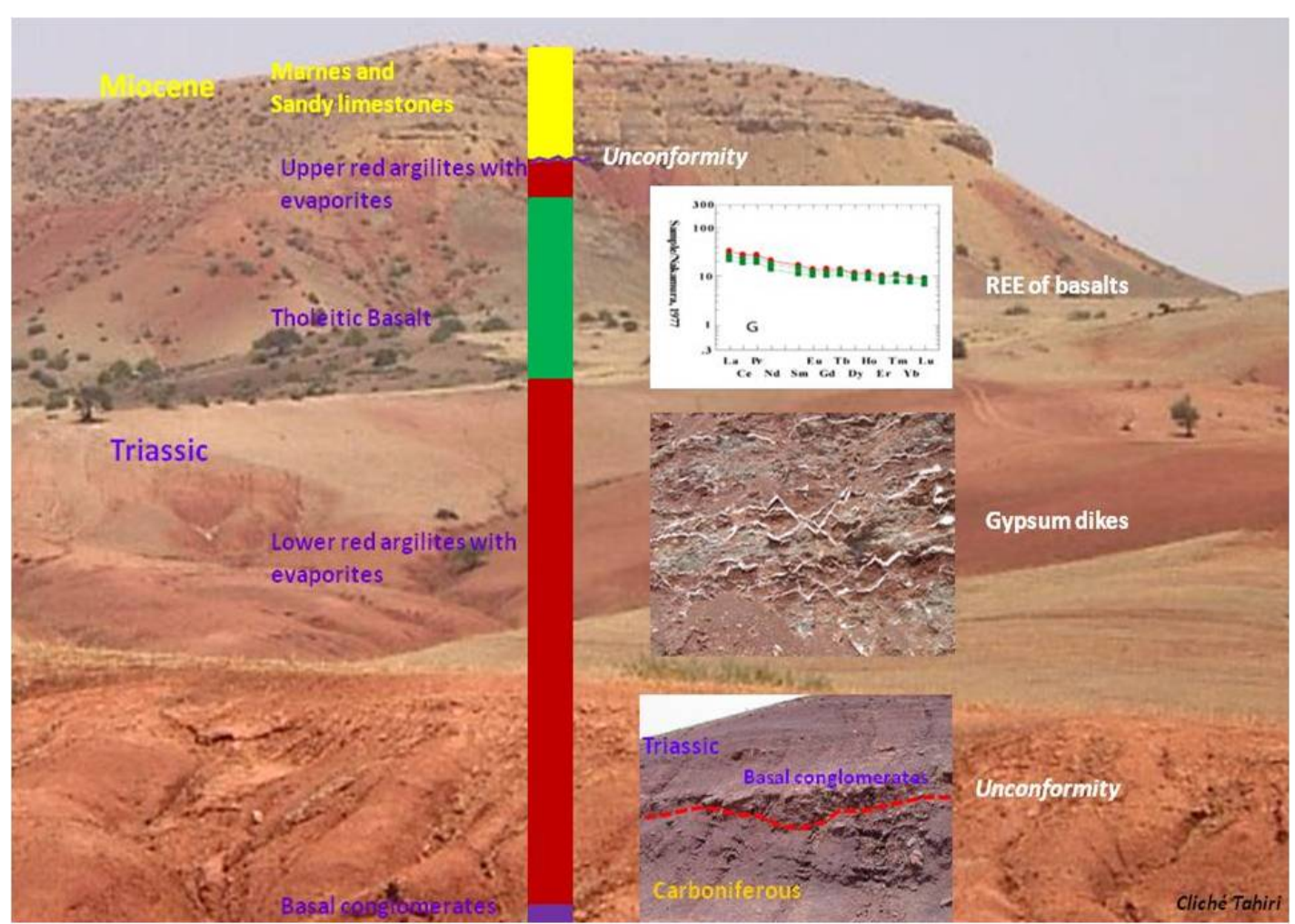

Figure 8. Triassic serie outcrop at Jmaa Moul Bled NE of Rommani, Central Morocco.

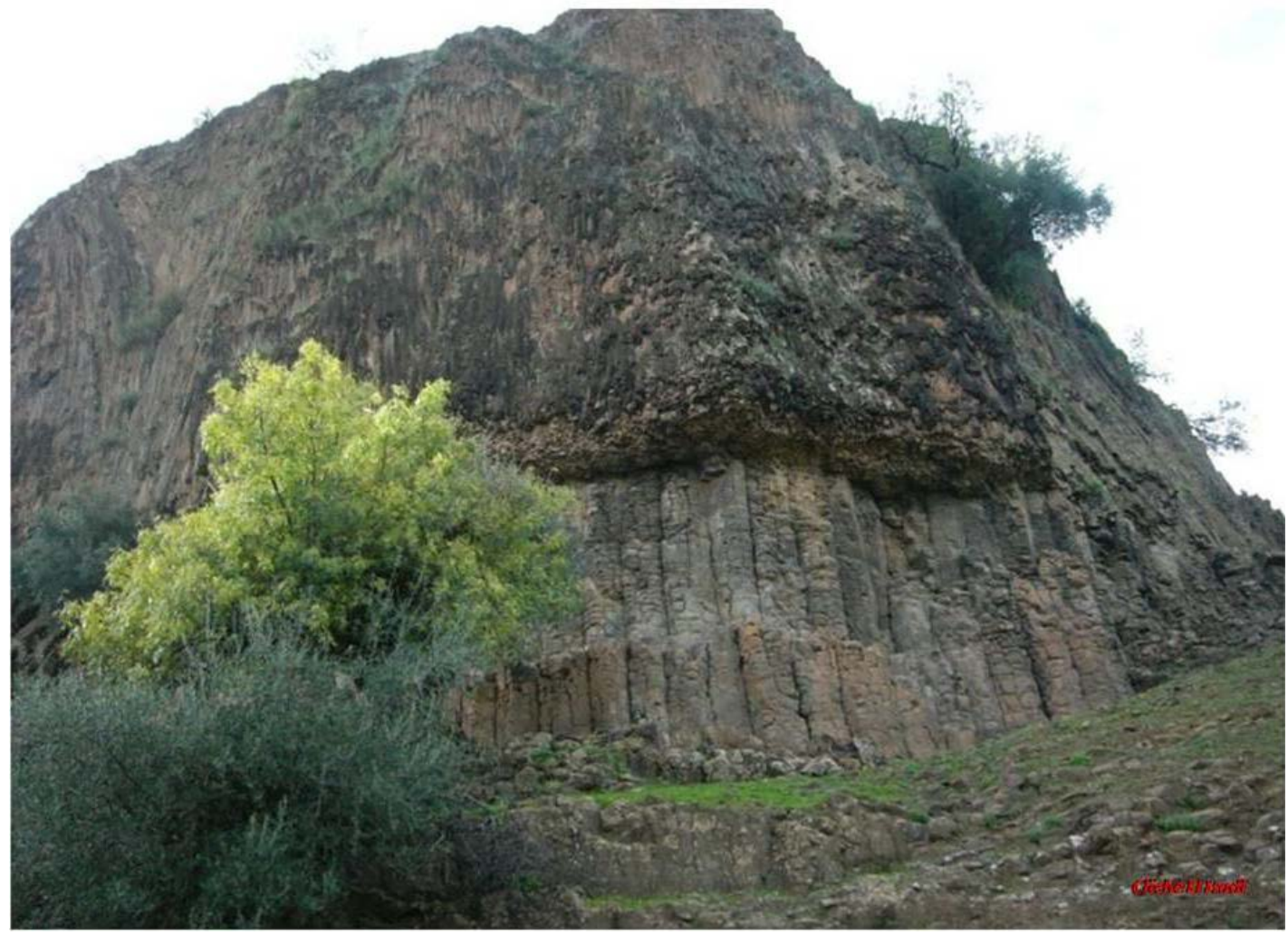

Figure 9. Prismatic nephelinites of Oued Boulahmayel SE of Oulmès, Central Morocco. 


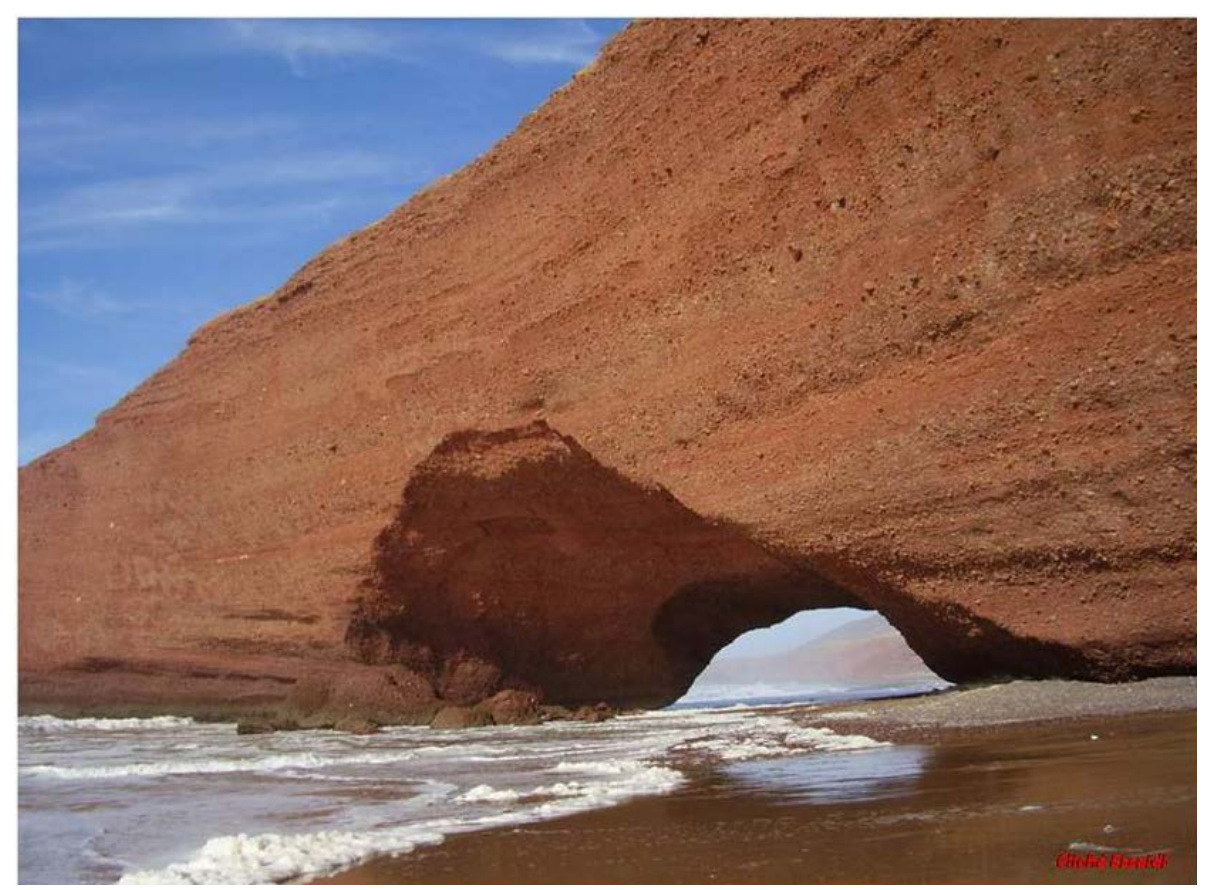

Figure 10. Legzira’s Arches (Ifni area).

strange natural and unique complex began around 110 million years. At this time, the region was occupied by torrential and fluvial systems whose conglomerate and sandstone deposits are witnesses. The sediment load consists essentially of clays, grains, granules and pebbles. This heterometric and polygenic sediment is discharged in large part in a subaerial environment and probably ends in low layer of water to form a fan-delta. Facies mostly lenticular structures reveal various "sheet-flow" oblique bedding, crossbedding and residual deposits (lag deposits) while the coarse clasts $(1-8 \mathrm{~cm}$ diameter) are relatively angular and poorly sorted. The granitic and volcanic nature of the elements reflects the erosion of neighboring reliefs composed mainly by Proterozoic bodies of Ifni inlier. Constantly attacked by waves and occasionally storms, this complex was transformed over time into a strange and attractive landscape by its shape and red ochre color. These natural arches of Mirleft certainly attractive are so fragile that their protection is needed.

\section{Conclusion}

Morocco disserves a geological richness well distributed throughout the country and which can be the lever of regional development in the context of a geological tourism. To this end, a global approach for geoconservation, taking into account all the skills of earth sciences, must be implemented. This will allow taking actions of natural potentialities at regional level.

\section{References}

[1] Michard, A., Hoepffner, C., Soulaimani, A. and Baidder, L. (2008) The Variscan Belt. In: Michard, A., Saddiqi, O., Chalouan, A. and Frizon de Lamotte, D., Eds., Continental Evolution: The Geology of Morocco, Springer, Berlin, 65-131. http://dx.doi.org/10.1007/978-3-540-77076-3_3

[2] Gray, J.M. (2008) Geodiversity: Developing the Paradigma. Proceedings of the Geologists’ Association, 119, $287-298$. http://dx.doi.org/10.1016/S0016-7878(08)80307-0

[3] Gray, J.M. (2013) Geodiversity: Valuing and Conserving Abiotic Nature. 2nd Edition, John Wiley \& Sons, Chichester.

[4] Wimbledon, W.A. (2011) Geosites: A Mechanism for Protection, Integrating National and International Valuation of Heritage Sites. Geologia dell'Ambiente, 2, 13-25.

[5] Brilha, J. (2015) Inventory and Quantitative Assessment of Geosites and Geodiversity Sites: A Review. Geoheritage. http://dx.doi.org/10.1007/s12371-014-0139-3

[6] El Hadi, H., Simancas, J.F., Martynez-Poyatos, D., Azor, A., Tahiri, A. Montero, A., Fanning, C.M., Bea, F. and Gon- 
zalez-Lodeiro, F. (2010) Structural and Geochronological Constraints on the Evolution of the Bou Azzer Neoproterozoic Ophiolite (Anti-Atlas, Morocco). Precambrian Research, 182, 1-14. http://dx.doi.org/10.1016/j.precamres.2010.06.011

[7] Tahiri, A., Montero, P., El Hadi, H., Martínez Poyatos, D., Azor, A., Bea, F., Simancas, J.F. and González Lodeiro, F. (2010) Geochronological Data on the Rabat-Tiflet Granitoids: Their Bearing on the Tectonics of the Moroccan Variscides. Journal of African Earth Sciences, 57, 1-13. http://dx.doi.org/10.1016/j.jafrearsci.2009.07.005

[8] Nahraoui, F.Z., El Wartiti, M., Zahraoui M. and Dabi, S. (2011) Geomorphosite Valorization: A View to Sustainable Development: Case of Ait Hajji, Oued Boulahmayel Valley, Central Morocco. Journal of Geographic Information System, 3, 12-17.

[9] Brilha, J.B. and Galopim de Carvalho, A.M. (2010) Geoconservação em Portugal: Uma introdução. In: Cotelo Neiva, J.M., Ribeiro, A., Mendes Victor, L., Noronha, F. and Magalhães Ramalho, M., Eds., Ciências Geológicas: Ensino, Investigação e sua História, Associação Portuguesa de Geólogos, Volume II, 435-441. http://hdl.handle.net/1822/10572

[10] Henriques, M.H., Pena dos Reis, R., Brilha, J. and Mota, T.S. (2011) Geoconservation as an Emerging Geoscience. Geoheritage, 3, 117-128. http://dx.doi.org/10.1007/s12371-011-0039-8

[11] Lima, F.F., Brilha, J. and Salamuni, E. (2010) Inventorying Geological Heritage in Large Territories: A Methodological Proposal Applied to Brazil. Geoheritage, 2, 91-99. http://dx.doi.org/10.1007/s12371-010-0014-9

[12] Michard, A., Saddiqi, O., Chalouane, A., Rjimati, E.C. and Moutaqi, A. (2011) Nouveaux guides géologiques et miniers du Maroc. In: Michard, A., et al., Eds., Notes et Mémoire du Service Géologique Maroc, 2011, 9V.

[13] Thomas, R.J., Fekkak, A., Ennih, N., Errami, E., Loughlin, S.C., Gresse, P.G., Chevallier, L.P. and Liégeois, J.P. (2004) A New Lithostratigraphic Framework for the Anti-Atlas Orogen, Morocco. Journal of African Earth Sciences, 39, 217-226. http://dx.doi.org/10.1016/j.jafrearsci.2004.07.046

[14] Walliser, O.H. (1991) Section Jebel Mech Irdane. In: Walliser, O.H., Ed., Morocco Field Meeting of the Subcommission on Devonian Stratigraphy, Guide Book, 25-48.

[15] Walliser, O.H. (1995) The Jebel Mech Irdane Section. Notes et Mémoire du Service Géologique Maroc, No. 399, 57-62, 4 fig.

[16] Brachert, T.C., Buggisch, W., Flügel, E., Hüssner, H.M., Joachimski, M.M., Tourneur, E. and Walliser, O.H. (1992) Controls of Mud Mounds Formation: The Early Devonian Kess-Kess Carbonates of the Hamar Laghdad, Anti-Atlas, Morocco. Geologische Rundschau, 81, 15-44. http://dx.doi.org/10.1007/BF01764537

[17] Belka, Z. (1998) Early Devonian Kess-Kess Carbonate Mud Mounds of the Eastern Anti-Atlas (Morocco), and Their Relation to Submarine Hydrothermal Venting. Journal of Sedimentary Research, 68, 368-377. http://dx.doi.org/10.2110/jsr.68.368

[18] Mounji, D., Bourque, P.A. and Savard, M.M. (1998) Hydrothermal Origin of Devonian Conical Mounds (Kess-Kess) of Hamar Lakhdad, Anti-Atlas, Morocco. Geology, 26, 1123-1126. http://dx.doi.org/10.1130/0091-7613(1998)026<1123:HOODCM>2.3.CO;2

[19] Cogney, G., Normand, M., Termier, H. and Termier, G. (1974) Observations sur le basalte du bassin triasique de Rommani-Maâziz (Maroc Oriental). Notes et Mémoire du Service Géologique Maroc, No. 264, 153-173.

[20] Cogney, G. and Faugeres, J. (1975) Précisions sur la mise en place des épanchements basaltiques des formations triasiques de la bordure septentrionale du Maroc central. Bulletin de la Societe Geologique de France, 7, 7-733.

[21] Et-Touhami, M. (1992) Le Trias évaporitique du bassin de Khémisset (Maroc central). Géométrie du dépôt, évolution sédimentaire, Géochimie. Thèse Université Lyon, 242 p.

[22] Taugourdeau-Lantz, J. and Dubois, R. (1979) Données palynologiques sue le Jurassique Calabrais: Argument pour le rapprochement Afrique-Europe et importance de novelles espèces de spores d'Equisetales. Revue de Micropaléontologie, 21, 208-220.

[23] Knight, K.B., Nomade, S., Renne, P.R., Marzoli, A., Bertrand, H. and Youbi, N. (2004) The Central Atlantic Magmatic Province at the Triassic-Jurassic Boundary: Paleomagnetic and ${ }^{40} \mathrm{Ar} /{ }^{39} \mathrm{Ar}$ Evidence from Morocco for Brief, Episodic Volcanism. Earth and Planetary Science Letters, 228, 143-160. http://dx.doi.org/10.1016/j.epsl.2004.09.022

[24] Bensalah, M.K., Youbi, N., Mata, J., Madeira, J., Martins, L., El Hachimi, H., Bertrand, H., Marzoli, A., Bellieni, G., Doblas, M., Font, E., Medina, F., Mahmoudi, A., Berraâouz, E.H., Miranda, R., Verati, C., De Min, A., Ben Abbou, M. and Zayane, R. (2013) The Jurassic-Cretaceous Basaltic Magmatism of the Oued El-Abid Syncline (High Atlas, Morocco): Physical Volcanology, Geochemistry and Geodynamic Implications. Journal of African Earth Sciences, 81, 60-81. http://dx.doi.org/10.1016/j.jafrearsci.2013.01.004

[25] Baudin, T., Chevremont, P., Razin, Ph., Thiéblemont, D., Rachdi, H., Roger, J., Benhaourch, R. and Winckel, A. (2001) Carte géologique du Maroc au 1/50 000, Feuille d’Oulmès. Mémoire explicatif. Notes et Mémoire du Service Géologique Maroc, No. 410, 77 p. 
[26] Rachdi, H. (1995) Etude du volcanisme plio-quaternaire du Maroc central: Pétrographie, géochimie et minéralogie. Comparaison avec les laves typiques du Moyen Atlas et du Rekkam (Maroc). Notes et Mémoire du Service Géologique Maroc, No. 381, 157 p. 